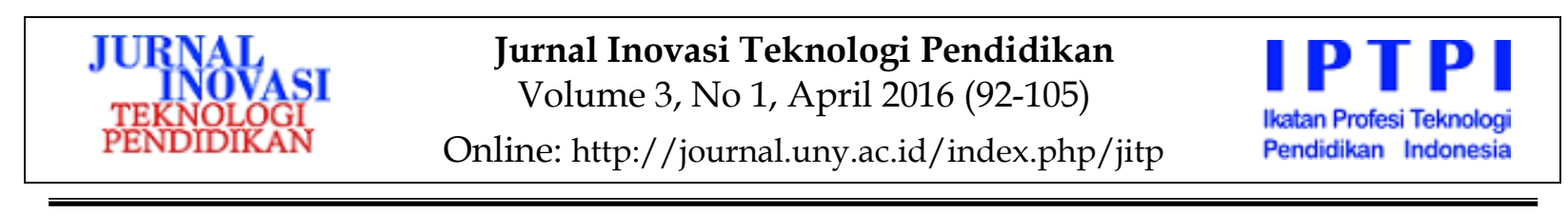

\title{
PENGEMBANGAN MULTIMEDIA AKUNTANSI BIAYA METODE HARGA POKOK PESANAN BAGI MAHASISWA JURUSAN PENDIDIKAN AKUNTANSI UNY
}

\author{
Sumarsih, Mukminan \\ Fakultas Ekononomi UNY, Fakultas Ilmu Sosial UNY \\ sumarsih@uny.ac.id, mukminan@yahoo.co.id
}

\begin{abstract}
Abstrak
Penelitian ini bertujuan untuk menghasilkan produk multimedia berupa CD pembelajaran Akuntansi Biaya Metode Harga Pokok Pesanan (AB-MHPP) yang layak bagi mahasiswa Jurusan Pendidikan Akuntansi, UNY. Di samping itu, penelitian ini juga dimaksudkan untuk mengetahui kelayakan dan keefektifan multimedia AB-MHPP untuk meningkatkan hasil belajar. Penelitian ini merupakan penelitian pengembangan. Subjek uji coba produk adalah mahasiswa Jurusan Pendidikan Akuntansi, UNY, yang didahului dengan telaah ahli media dan ahli materi. Uji coba dilakukan tiga kali, yaitu uji coba individu, uji coba kelompok kecil, dan uji kefektifan multimedia dengan membandingkan hasil kelompok eksperimen dengan kelompok kontrol. Analisis yang digunakan adalah analisis deskriptif pada setiap tahap pengembangan, dan dilanjutkan analisis statistik uji-t untuk mengetahui keefektifan media yang dikembangkan untuk meningkatkan hasil belajar. Hasil penelitian menunjukkan bahwa (1) Multimedia pembelajaran AB-MHPP dapat dinyatakan layak ditinjau dari aspek pembelajaran, materi, dan media; (2) Multimedia pembelajaran AB-MHPP efektif untuk meningkatkan hasil belajar akuntansi biaya metode harga pokok pesanan.
\end{abstract}

Kata kunci: multimedia pembelajaran AB-MHPP

\section{DEVELOPING THE TEACHING MULTIMEDIA OF THE COST ACCOUNTING OF JOB ORDER COSTING METHOD FOR STUDENTS OF ACCOUNTING EDUCATION DEPARTMENT, YSU}

\author{
Sumarsih, Mukminan \\ Fakultas Ekononomi UNY, Fakultas Ilmu Sosial UNY \\ sumarsih@uny.ac.id, mukminan@yahoo.co.id
}

\begin{abstract}
This research aims to produce the instructional multimedia of the CAJOCM appropriate for students of Accounting Education Department, YSU. This study also aimed to determine the feasibility and effectiveness of multimedia CAJOCM to improve learning outcomes. This research include the research and development. The subjects of the products try out were students of Accounting Education Department, YSU, which was preceded by media and material expert's validation. The try out was carried out three times, namely the individual trials, testing a small group, and test a large group. The analysis used was descriptive analysis at each stage of development, and continued by inferential analysis to determine the effectiveness of the media that was developed. The results show that (1) The CAJOCM instructional multimedia is feasible in terms of aspects of learning, materials, and media; (2) The CAJOCM teaching multimedia is an effective way to improve learning outcomes of CAJOCM.
\end{abstract}

Keywords: instructional multimedia, CAJOCM 



\section{Pendahuluan}

Akuntansi biaya merupakan salah satu mata kuliah yang terdapat di semua Jurusan Pendidikan Akuntansi. Mata kuliah ini bertujuan untuk mempersiapkan mahasiswa agar mampu mengelola perusahaan manufaktur khususnya dalam pengelolaan biaya. Berbagai permasalahan muncul dalam proses pembelajaran Akuntansi Biaya, khususnya di Jurusan Pendidikan Akuntansi FE UNY. Sebagai contoh, kondisi pembelajaran menyangkut ruangan, selama ini kursi kuliah terlalu berdempetan sehingga terasa sekali ketidaknyamanannya. Ruang kuliah yang tidak terlalu luas, diisi dengan jumlah mahasiswa melebihi kapasitas yang seharusnya. Hal ini dapat memberikan peluang bagi mahasiswa untuk tidak jujur dan bekerjasama dalam mengerjakan ujian yang kadang-kadang dosen kurang dapat mengendalikan karena memang kondisinya semacam itu.

Selain permasalahan ruangan, dalam persiapan pembelajaran, dosen hanya mempersiapkan materi, namun masih jarang menyiapkan media pembelajaran yang mendukung. Dalam proses pembelajaran Akuntansi Biaya, selama ini hanya persiapan materi dan banyak menyodorkan soal latihan dengan cara membagi soal atau didekte, mahasiswa mengerjakan di buku, salah seorang mahasiswa mengerjakan di papan tulis dan dosen membantu memecahkan/mengerjakan soal kalau mahasiswa menghadapi kesulitan. Sedangkan kesiapan mahasiswa, walaupun telah dipaparkan silabus, telah diberitahu bukubuku yang digunakan oleh dosen belum tentu minggu kedua, atau ketiga bahkan sampai akhir perkuliahan tetap tidak memiliki buku, selain catatan kuliah, dan bila diadakan pertanyaan pendahuluan kentara kalau belum membaca sebelumnya. Sampai saat ini belum ada media yang sesuai untuk mendukung kegiatan belajar Akuntansi Biaya. Belum ada dosen, khususnya di Jurusan Pendidikan Akuntansi yang mengembangkan media pembelajaran Akun- tansi Biaya, terlebih yang berbasis komputer.

Tidak adanya media pembelajaran dapat menghambat proses pembelajaran. Hal ini disebabkan tidak munculnya reaksi mahasiswa. Padahal dalam kegiatan belajar, respon dan reaksi merupakan hal yang penting. Hal ini seperti yang diungkapkan oleh Thorndike (dalam Slavin, 2000) bahwa belajar merupakan proses interaksi antara stimulus berupa rangsangan terjadinya kegiatan belajar yakni pikiran, perasaan yang ditangkap melalui pancaindera dan respon yaitu reaksi siswa waktu belajar berupa pikiran, perasaan dan tindakan. Menurut Skinner dalam Budiningsih (2005, p.24), hubungan antara stimulus dan respon yang terjadi melalui interaksi dalam lingkungan, yang kemudian akan menimbulkan perubahan tingkahlaku. Stimulusstimulus yang diberikan pada seseorang akan saling berinteraksi dan interaksi antara stimulus-stimulus tersebut akan mempengaruhi bentuk respon yang akan diberikan. Tidak adanya reaksi mahasiswa dapat disimpulkan bahwa proses pembelajaran tidak berjalan sesuai dengan apa yang seharusnya. Hal ini menuntut dosen agar mampu untuk mendesain pembelajaran yang tepat bagi mahasiswa. Pada dasarnya pembelajaran merupakan proses interaktif siswa, guru, dan sumber belajar pada suatu lingkungan belajar yang membantu siswa agar dapat belajar dengan baik. Sedangkan desain pembelajaran merupakan satuansatuan tertentu yang terdiri dari standar kompetensi, kompetensi dasar mata kuliah, materi pokok, kegiatan belajar mengajar, serta sistem penilaian. Dengan mempersiapkan desain pembelajaran dapat menghasilkan pembelajaran yang efektif dan menarik.

Permasalahan lain yang muncul adalah permasalahan ditinjau dari prestasi belajar mahasiswa yang menempuh mata kuliah Akuntansi Biaya. Prestasi belajar mahasiswa selama ini dapat dikatakan baik, namun hal tersebut bukan dari hasil ujian saja, tetapi lebih pada nilai tambah dari tugas-tugas selama proses pembel- 
ajaran berlangsung. Apabila prestasi belajar hanya diukur dari hasil ujian tanpa ditambah nilai tugas maka yang lulus hanya $60 \%$ saja.

Permasalahan-permasalahan tersebut perlu diatasi agar pembelajaran menjadi lebih baik, prestasi belajar meningkat, dengan cara perbaikan dalam proses pembelajaran. Mahasiswa perlu diberikan pengalaman nyata sehingga memudahkan mahasiswa memahami materi yang selama ini mahasiswa menganggap Akuntansi Biaya merupakan mata kuliah yang sulit. Apabila mahasiswa merasa mudah maka motivasi belajar akan tumbuh dan akan meningkatkan prestasi belajarnya.

Pencapaian tujuan pembelajaran terutama untuk peningkatan prestasi belajar yang nilainya berasal dari ujian diperlukan adanya perubahan antara lain dengan menggunakan multimedia. Penggunaan multimedia syaratnya memanfaatkan komputer. Pemanfaatan komputer untuk memecahkan masalah belajar dan mendorong kegiatan pembelajaran mahasiswa sesuai dengan fungsi multimedia memiliki arti bahwa multimedia digunakan untuk belajar secara individual.

Teori belajar menurut Thorndike (dalam Slavin, 2000) yang dikenal dengan aliran Koneksionisme, belajar adalah proses interaksi antara stimulus berupa rangsangan terjadinya kegiatan belajar yakni pikiran, perasaan yang ditangkap melalui pancaindera dan respon yaitu reaksi siswa waktu belajar berupa pikiran, perasaan dan tindakan. Watson (dalam Uno, 2008, p. 7) mengatakan belajar merupakan interaksi antara stimulus dan respon, keduanya berbentuk tingkah laku yang dapat diamati dan dapat diukur. Clark Hull (dalam Bell Gredler, 1991) menghubungkan antara stimulus dan respon dalam belajar dengan kebutuhan biologis. Seseorang yang melaksanakan kegiatan belajar akan melakukan interaksi dan akan memberikanrespon terhadap apa yang mereka kerjakan.

Di sisi lain, agar kegiatan belajar dapat berjalan dengan baik, diperlukan pembelajaran yang baik pula. Menurut
Driscoll (1994) dalam Newby (2000, p.10), pengertian pembelajaran adalah "a persisting change in human performance or performance potential (brought) about as a result of the learner's interaction with the environment". Istilah pembelajaran merupakan terjemahan kata "instruction". Pembelajaran merupakan serangkaian kegiatan yang memungkinkan terjadinya proses belajar pada mahasiswa. Teori Gestalt memandang belajar adalah proses yang didasarkan pemahaman (insight) sehingga dalam proses belajar yang penting adalah dimengertinya apa yang dipelajari individu tersebut. Pembelajaran yang baik adalah pembelajaran yang dapat memberikan pemahaman terhadap individu yang terlibat dalam pembelajaran tersebut.

Pembelajaran yang dapat memberikan pemahaman terhadap individu memerlukan desain pembelajaran yang tepat agar pembelajaran berjalan efektif. Desain pembelajaran adalah kisi-kisi penerapan teori belajar dan pembelajaran untuk memfasilitasi proses belajar seseorang. Desain pembelajaran membantu proses belajar seseorang, proses belajar memiliki tahapan segera dan jangka panjang, proses belajar terjadi karena kondisi-kondisi pembelajar baik internal maupun eksternal. Terdapat lima asumsi dasar yang mendasari perlunya desain pembelajaran, yaitu: (1) diarahkan untuk membantu proses belajar individual; (2) desain pembelajaran mempunyai fase jangka pendek dan jangka panjang; (3) dapat mempengaruhi perkembang-an individu secara maksimal; (4) didasarkan pada pengetahuan tentang cara belajar manusia; dan (5) dilakukan dengan menerapkan pendekatan sistem (Mukminan, 2006, p.19). Dengan desain pembelajaran yang sesuai diharapkan akan dicapai perbaikan pembelajaran.

Perbaikan pembelajaran dilakukan dengan memanfaatkan komputer dan internet sebagai media pembelajaran bagi mahasiswa. Namun, pelaksanaan pembelajaran dengan komputer atau multimedia tidak cukup tersedia komputer saja, tetapi perlu ada aplikasi pendukung untuk memper- 
mudah mahasiswa di dalam belajar. Sampai saat ini belum ada aplikasi yang dapat digunakan mahasiswa dalam belajar Akuntansi Biaya, sehingga mahasiswa masih mengalami kesulitan belajar, tidak ada motivasi belajar, dan hasil belajar kurang memuaskan. Oleh sebab itu, permasalahan dalam penelitian ini difokuskan pada pengembangan multimedia aplikasi Akuntansi Biaya, khususnya Akuntansi Biaya Metode Harga Pokok Pesanan.

\section{Metode Penelitian}

Penelitian ini merupakan penelitian pengembangan, yaitu pengembangan multimedia pembelajaran Akuntansi Biaya Metode Harga Pokok Pesanan bagi mahasiswa Jurusan Pendidikan Akuntansi FE UNY. Penelitian ini dilaksanakan di Jurusan Pendidikan Akuntansi Fakultas Ekonomi Universitas Negeri Yogyakarta.

Model pengembangan produk multimedia pembelajaran yang digunakan dalam penelitian ini adalah mengadaptasi dua model pengembangan yaitu desain pembelajaran mengadaptasi model desain pembelajaran Dick, Carrey \& Carrey (2005, p.1) dan pengembangan produk multimedia pembelajaran mengadaptasi model Borg \& Gall (1983, 775). Kedua model pengembangan tersebut dipilih karena ada hubungan yang erat antara pengembangan desain pembelajaran dan pengembangan produk multimedia. Dari adaptasi kedua model pengembangan tersebut diharapkan dapat menghasilkan sebuah model desain pengembangan produk yang cocok digunakan dalam mengembangkan multimedia pembelajaran AB-MHPP untuk pembelajaran di program studi Akuntansi FE UNY.

Prosedur penelitian pengembangan multimedia terdiri enam tahap, yaitu: (1) menentukan mata kuliah; (2) mengidentifikasi silabus mata kuliah; (3) desain pembelajaran; (4) produksi media; (5) evaluasi produk; dan (6) produk akhir.

Uji coba yang dilakukan meliputi uji coba perorangan, uji coba kelompok kecil, dan uji lapangan. Subjek uji coba pro- duk multimedia pembelajaran yang dikembangkan adalah mahasiswa Jurusan Pendidikan Akuntansi sejumlah 43 mahasiswa, 3 mahasiswa untuk uji coba perorangan, 10 mahasiswa untuk uji coba kelompok kecil, 30 mahasiswa untuk uji coba lapangan. Mahasiswa yang dijadikan uji coba mahasiswa Program studi Akuntansi semester 3 dan yang dipakai uji lapangan mahasiswa Program Studi Akuntansi semester 3 tahun berikutnya.

Pengumpulan data yang digunakan sebagai dasar dalam menetapkan kelayakan, keefektifan dan daya tarik multimedia pembelajaran yang dikembangkan meliputi: ketepatan desain pembelajaran dari ahli materi dan desain media dari ahli media, keefektifan materi yang disajikan dalam produk $C D$ pembelajaran diperoleh dari kompetensi yang ditetapkan, efisiensi waktu dalam pembelajaran dengan menggunakan produk CD pembelajaran, diperoleh dari kecepatan unjuk kerja pembelajaran dan jumlah waktu yang diperlukan (30 menit soal teori dan 60 menit soal praktik), dan kelayakan produk diperoleh dari hasil penilaian uji coba perorangan dan uji lapangan terhadap aspek isi pembelajaran, aspek instruksional, aspek tampilan dan aspek pemrograman.

Instrumen pengumpulan data yang digunakan dalam penelitian pengembangan ini berupa kuesioner untuk mengukur kualitas produk yang dikembangkan, ditinjau dari isi pembelajaran, aspek intruksional, aspek tampilan, dan aspek pemrograman.

Data yang dikumpulkan dari uji lapangan dianalisis dengan teknik analisis secara deskripstif. Data yang diperoleh dari kuesioner tentang tanggapan mahasiswa diubah menjadi data interval. Di dalam kuesioner diberikan lima pilihan untuk memberikan tanggapan produk multimedia pembelajaran yang dikembangkan yaitu: sangat baik $=5$, baik $=4$, cukup baik $=3$, kurang baik $=2$, sangat kurang baik $=1$ (Sukardjo, 2006, p.55). Untuk mengkonversi skor ke nilai skala 5 digunakan pedoman konversi seperti pada Tabel 1. 
Tabel 1. Pedoman Konversi Skor ke Nilai pada Skala 5

\begin{tabular}{llll}
\hline $\begin{array}{l}\text { No Formula Penentuan Rentang } \\
\text { Skor }\end{array}$ & Kode & Kategori \\
\hline 1 & $\mathrm{Mi}+1,8 \mathrm{Sdi} \leq \mathrm{X}$ & A & Sangat Baik \\
$2 \mathrm{Mi}+0,6 \mathrm{Sdi} \leq \mathrm{X}<\mathrm{Mi}+1,8 \mathrm{Sdi}$ & B & Baik \\
$3 \mathrm{Mi}-0,6 \mathrm{Sdi} \leq \mathrm{X}<\mathrm{Mi}+0,6 \mathrm{Sdi}$ & $\mathrm{C}$ & Cukup Baik \\
$4 \mathrm{Mi}-1,8 \mathrm{Sdi} \leq \mathrm{X}<\mathrm{Mi}-0,6 \mathrm{Sdi}$ & $\mathrm{D}$ & Kurang Baik \\
$5 \mathrm{X}<\mathrm{Mi}-1,8 \mathrm{Sdi}$ & E & Sangat \\
& & & Kurang Baik \\
\hline
\end{tabular}

Keterangan:

$\mathrm{Mi}=$ Rerata ideal $=1 / 2$ (skor maksimal ideal + skor minimal ideal)

Sdi = Simpangan baku ideal $=1 / 6$ (Skor maksimal ideal - skor minimal ideal)

$\mathrm{X}=$ Skor aktual

Dalam mencari skor rata-rata untuk memberikan penilaian produk multimedia yang dikembangkan digunakan rumus:

$$
\bar{X}=\frac{1}{n} \sum_{i=1}^{n} X_{i}
$$

Keterangan:

$\bar{X}=$ Rata-rata skor

$X_{i}=$ Skor observasi, $(i=1,2,3, \ldots n)$

$n=$ Jumlah Responden

Berdasarkan rumus tersebut, pedoman konversi data kuantitatif menjadi data kualitatif untuk skor setiap butir pertanyaan disajikan pada Tabel 2.

Penilaian keefektifan multimedia dalam pembelajaran menggunakan penilaian ketuntasan belajar. Pedoman konversi prestasi belajar dari data kuantitatif menjadi data kualitatif disajikan pada Tabel 3.

Kriteria pertama yang ditetapkan untuk menilai keberhasilan pembelajaran dengan pemakaian multimedia CD pembelajaran dalam penelitian ini apabila mahasiswa yang masuk kategori sangat baik dan baik yakni sangat baik (di atas 79,9 ) dan baik yakni 60,0 -79,9. Kriteria kedua untuk menilai keberhasilan pembelajaran dengan multimedia CD pembelajaran adalah dengan menganalisis data hasil pretest dan posttest dianalisis dengan menggunakan $t$-test dengan rumus sebagai berikut.

$$
\begin{aligned}
& t=\frac{\bar{d}}{s_{\bar{d}}} \\
& d_{i}=\left(X_{2}-X_{1}\right)_{i} \\
& \vec{d}=\frac{1}{n} \sum_{i=1}^{n} d_{i} \\
& s_{\vec{d}}=\frac{n \sum_{i=1}^{n} d_{i}^{2}-\left(\sum_{i=1}^{n} d_{i}\right)^{2}}{n(n-1)}
\end{aligned}
$$

Tabel 2. Pedoman Konversi Data Kuantitatif menjadi Data Kualitatif untuk Skor setiap Butir Pertanyaan

\begin{tabular}{cccc}
\hline Kode & Formula Penentuan Rentang Skor & Hitungan & Rentang Skor \\
\hline $\mathrm{A}$ & $\mathrm{Mi}+1,8 \mathrm{Sdi} \leq \mathrm{X}$ & $4.21 \leq \mathrm{X}$ & $4.21-5.00$ \\
$\mathrm{~B}$ & $\mathrm{Mi}+0,6 \mathrm{Sdi} \leq \mathrm{X}<\mathrm{Mi}+1.8 \mathrm{Sdi}$ & $3.40 \leq \mathrm{X}<4.21$ & $3.40-4.20$ \\
$\mathrm{C}$ & $\mathrm{Mi}-0.6 \mathrm{Sdi} \leq \mathrm{X}<\mathrm{Mi}+0.6 \mathrm{Sdi}$ & $2.60 \leq \mathrm{X}<3.40$ & $2.60-3.39$ \\
$\mathrm{D}$ & $\mathrm{Mi}-1.8 \mathrm{Sdi} \leq \mathrm{X}<\mathrm{Mi}-0.6 \mathrm{Sdi}$ & $1.79 \leq \mathrm{X}<2.60$ & $1.79-2.59$ \\
$\mathrm{E}$ & $\mathrm{X}<\mathrm{Mi}-1.8 \mathrm{Sdi}$ & $\mathrm{X}<1.79$ & $1.00-1.78$ \\
\hline
\end{tabular}

Tabel 3. Pedoman Konversi Data Kuantitatif menjadi Data Kualitatif untuk Skor Setiap Individu

\begin{tabular}{lccc}
\hline Kode & Formula Penentuan Rentang Skor & Hitungan & Rentang Skor \\
\hline $\mathrm{A}$ & $\mathrm{Mi}+1.8 \mathrm{Sdi} \leq \mathrm{X}$ & $80.0 \leq \mathrm{X}$ & $80.0-100$ \\
$\mathrm{~B}$ & $\mathrm{Mi}+0.6 \mathrm{Sdi} \leq \mathrm{X}<\mathrm{Mi}+1.8 \mathrm{Sdi}$ & $60.0 \leq \mathrm{X}<80.0$ & $60.0-89.9$ \\
$\mathrm{C}$ & $\mathrm{Mi}-0.6 \mathrm{Sdi} \leq \mathrm{X}<\mathrm{Mi}+0.6 \mathrm{Sdi}$ & $40.0 \leq \mathrm{X}<60.0$ & $40.0-59.9$ \\
$\mathrm{D}$ & $\mathrm{Mi}-1.8 \mathrm{Sdi} \leq \mathrm{X}<\mathrm{Mi}-0.6 \mathrm{Sdi}$ & $20.0 \leq \mathrm{X}<40.0$ & $20.0-39.9$ \\
$\mathrm{E}$ & $\mathrm{X}<\mathrm{Mi}-1.8 \mathrm{Sdi}$ & $\mathrm{X}<20.0$ & $00.0-19.9$ \\
\hline
\end{tabular}


Keterangan:

$X_{1}=$ Skor sebelum diberikan media,

$X_{2}=$ Skor setelah diberikan media,

$d_{i}=$ Selisih skor sebelum dan setelah diberikan media, $(i=1,2,3, \ldots n)$,

$\bar{d}=$ Rata-rata selisih skor,

$s_{\bar{d}}=$ Simpangan baku selisih skor,

$n$ = Jumlah observasi.

Hasil yang diperoleh dari analisis ttest tersebut selanjutnya dikonsul-tasikan dengan tabel $t$ pada signifikansi $(\alpha=0.05)$ dan derajad bebas $(\mathrm{db}=n-2)$. Hal ini untuk melihat apakah ada perbedaan yang signifikan antara hasil skor sebelum dan setelah diberikan media (pretest dan posttest), sehingga dapat diambil kesimpulan tentang keefektifan penggunaan multimedia pembelajaran yang dikembangkan.

\section{Hasil Penelitian}

Hasil Uji coba Produk

Uji coba produk multimedia pembelajaran AB-MHPP secara empiris dilakukan dengan tiga tahap, yaitu uji coba perorangan, uji coba kelompok kecil, dan uji coba kelompok besar (operasional). Hasil uji coba produk ini merupakan tanggapan pengguna yang memanfaatkannya sebagai validasi empiris mengenai kelayakan produk multimedia pembelajaran AB-MHPP yang dikembangkan.

\section{Deskripsi Data Hasil Uji coba Perorangan}

Uji coba tahap pertama dilaksanakan setelah revisi produk tahap pertama yakni revisi setelah multimedia akuntansi biaya metode harga pokok pesanan divalidasi oleh ahli materi dan ahli media pembelajaran. Pada uji coba tahap pertama ini dilakukan uji coba perorangan yang terdiri dari tiga orang mahasiswa.

Untuk mendapatkan data yang valid dari pelaksanaan uji coba, dipilih tiga orang mahasiswa untuk dijadikan subyek uji coba dengan didasarkan pada tingkat kemampuan mahasiswa, yaitu satu orang mahasiswa dengan kemampuan tinggi, satu orang mahasiswa dengan kemampuan sedang, dan satu orang mahasiswa dengan kemampuan kurang. Hal ini dilakukan untuk mengetahui dampak penggunaan multimedia akuntansi biaya metode harga pokok pesanan yang telah dikembangkan terhadap mahasiswa dengan berbagai kemampuan, sehingga multimedia pembelajaran yang dikembangkan dapat digunakan oleh semua mahasiswa.

Uji coba tahap pertama dilaksanakan dengan tujuan untuk mengidentifikasi kekurangan produk multimedia pembelajaran yang telah divalidasi oleh ahli materi dan ahli media serta untuk direvisi dari sudut mahasiswa. Pada uji coba ini mahasiswa diminta untuk mengamati dan mempelajari isi multimedia pembelajaran akuntansi biaya metode harga pokok pesanan. Setelah mahasiswa mengamati dan mempelajari isi multimedia pembelajaran akuntansi biaya metode harga pokok pesanan, mahasiswa kemudian diminta untuk mengisi lembar evaluasi penilaian. Penilaian pada uji coba ini meliputi aspek pembelajaran, aspek materi, aspek media, saran terbuka serta kesimpulan layak ti-daknya multimedia pembelajaran AB-MHPP.

Saran berdasarkan hasil uji coba perorangan meliputi: kemudahan pemahaman teks materi sebaiknya diperbaiki, terlalu banyak slide, sehingga jenuh memperhatikan materi, audio tidak terdengar, sehingga perlu diperbaiki. Bahasa dan teks agar dibuat lebih mudah dipahami.

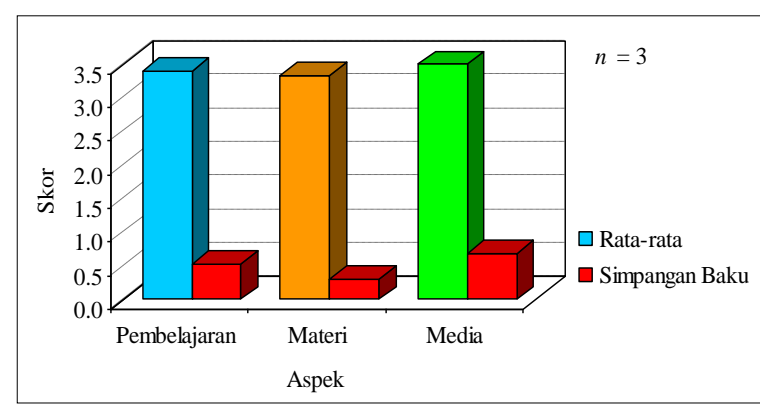

Gambar 1. Skor Rata-rata dan Simpangan Baku Hasil Uji coba

Perorangan pada Setiap Aspek

Ketiga mahasiswa subyek uji coba menyatakan multimedia pembelajaran 
akuntansi biaya metode harga pokok pesanan layak digunakan, dengan masing rata-rata menilai Aspek pembelajaran 3,40 (baik), aspek materi 3,33 (cukup baik), aspek media 3,50 (baik). Ketiga mahasiswa juga memberikan alasan mudah digunakan dan lebih memudahkan materi untuk dipahami.

Berdasarkan uji coba terhadap perorangan yang berjumlah tiga orang mahasiswa, dinyatakan bahwa multimedia pembelajaran akuntansi biaya metode harga pokok pesanan layak untuk digunakan. Namun, ada beberapa hal yang membuat pengguna multimedia mengalami kesulitan, diantaranya: (1) materi yang ada dalam media terlalu sulit untuk tingkatan mahasiswa; (2) fitur tambahan seperti musik dan video tidak dapat dimunculkan karena perbedaan spesifikasi teknologi yang digunakan masing-masing pengguna berbeda; (3) gambar-gambar yang disajikan kurang menarik sehingga membuat pengguna kurang tertarik; dan (4) Beberapa hyperlink tidak sesuai dengan slide yang akan dituju sehingga membuat bingung pengguna dalam memahami materi.

Berdasarkan uji coba perorangan dan saran yang diberikan mahasiswa, maka revisi yang dilakukan: (1) materi disesuaikan dengan kebutuhan mahasiswa, namun tidak mengabaikan kelengkapan cakupan materi sehingga harapannya mahasiswa tetap memperoleh materi yang komprehensif tetapi lebih mudah untuk mempelajarinya; (2) Multimedia pembelajaran dibuat sedemikian rupa sehingga dapat digunakan untuk spesifikasi teknologi yang lain, walaupun tetap terbatas; (3) menambahkan gambar-gambar disertai dengan animasi yang menarik namun tetap sesuai dengan isi slide sehingga tidak terjadi pengadaan gambar yang menyimpang dari tujuan yang diharapkan; dan (4) memperbaiki setiap hyperlink yang ada sehingga tidak terjadi kesalahan dalam pengoperasian dan kesalahan dalam pemahaman materi.

\section{Deskripsi Data Hasil Uji coba Kelompok} Kecil

Uji coba pada tahap kedua dilaksanakan pada kelompok kecil yang terdiri dari sepuluh orang mahasiswa. Uji coba tahap kedua ini bertujuan untuk mengidentifikasi kekurangan produk multimedia pembelajaran setelah perbaikan uji coba perorangan. Penilaian pada uji coba kelompok kecil ini meliputi aspek pembelajaran, aspek materi, aspek media, saran terbuka, dan kesimpulan layak tidaknya multimedia digunakan. Kesepuluh mahasiswa secara keseluruhan menilai aspek pembelajara rata-rata 3,40 (baik), aspek materi 3,52 (baik), aspek media 3,40 (baik).

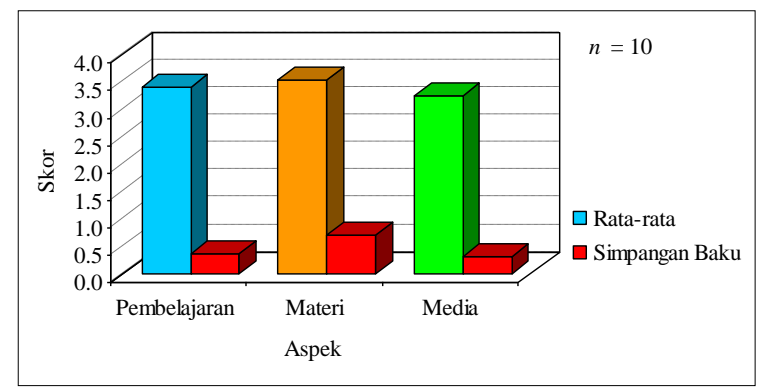

Gambar 2. Skor Rata-rata dan Simpangan Baku Hasil Uji coba Kelompok Kecil pada Setiap Aspek

Kesepuluh mahasiswa memberikan saran untuk bahan perbaikan bervariasi meliputi: susunan materi, slide terlalu banyak, variasi monoton, evaluasi, perlu penambahan materi, lebih baik diberikan di kelas agar komunikatif. Dari sepuluh mahasiswa delapan mahasiswa menyatakan multimedia akuntansi biaya metode harga pokok pesanan layak digunakan, dua orang mahasiswa menyatakan kurang layak digunakan. Mahasiswa yang menyatakan layak alasannya: teks mudah dibaca, warna menarik, materi sesuai kompetensi yang hendak dicapai, materi cukup lengkap, jelas, dan mudah dipahami.

Berdasarkan uji coba terhadap sepuluh orang mahasiswa multimedia akuntansi biaya delapan orang menyatakan layak digunakan. Mahasiswa lebih tertarik mempelajari akuntansi biaya khususnya 
metode harga pokok pesanan karena dapat memperdalam materi dengan bantuan multimedia yang disajikan. Tetapi masih ada beberapa hal yang perlu diperhatikan dikarenakan beberapa orang masih mengalami kesulitan dalam memahami materi yang disajikan, dan ada dua orang mahasiswa yang menyatakan kurang layak digunakan. Hal-hal yang masih perlu diperbaiki meliputi: (1) bahasa yang digunakan sulit untuk dipahami karena kendala bahasa asing (Inggris) yang digunakan dalam media tersebut sehingga membuat pengguna harus berpikir dua kali untuk memahami materi yang disajikan; (2) poin-poin dalam slide tidak ada penjelasan secara rinci sehingga kadang pengguna mengalami kebingungan; (3) musik dan video yang disajikan kurang sesuai dengan materi yang ditampilkan sehingga tidak dapat membantu pengguna untuk melekatkan materi ke dalam ingatan mereka.

Beberapa perbaikan yang dilakukan untuk perbaikan media meliputi: (1) hampir semua kata dalam bahasa Inggris diubah ke dalam bahasa Indonesia, kecuali untuk istilah yang sulit dicari padanan dalam bahasa Indonesia, harapannya agar pengguna lebih mudah memahami materi. Selain itu jika ada penambahan materi, disajikan dengan menggunakan bahasa Indonesia; (2) Penggantian musik dengan suara tutor sehingga lebih membantu pengguna dalam memahami materi akuntansi biaya dan hal ini menimbulkan kesan lebih sederhana pada setiap slide yang disajikan sehingga terlihat lebih menarik.

\section{Deskripsi Data Hasil Uji coba Kelompok Besar}

Uji coba lapangan merupakan uji coba tahap ketiga setelah revisi produk setelah uji coba tahap kedua. Pada uji coba tahap ketiga ini dilakukan uji coba lapangan dengan subyek uji coba terdiri dari tiga puluh orang mahasiswa. Uji coba tahap ketiga ini dilakukan dengan tujuan untuk mengidentifikasi kekurangan produk multimedia pembelajaran jika di- gunakan secara klasikal, kemudian untuk merevisi produk multimedia agar menjadi sempurna di kemudian hari. Hasil respon mahasiswa terhadap produk multimedia akuntansi biaya metode harga pokok pesanan meliputi: aspek pembelajaran, aspek materi, aspek media, saran, dan kesimpulan layak tidaknya produk multimedia hasil pengembangan digunakan.

Ketigapuluh mahasiswa seluruhnya menyatakan bahwa multimedia akuntansi biaya metode harga pokok pesanan layak dapat digunakan. Beberapa alasan yang dikemukakan mahasiswa antara lain karena tampilan menarik, keinginan belajar menguat, membuat otak mudah mengingat, memotivasi belajar, mudah mengingat materi, membantu pemahaman materi, penyajian materi lengkap, mendukung proses belajar, untuk mengikuti kemajuan teknologi, tidak membosankan, materi lengkap, lebih bervariasi, dan akan memaksimalkan hasil belajar.

Media pembelajaran akuntansi biaya dinyatakan baik/bagus dan memberikan motivasi bagi pengguna/mahasiswa dalam mempelajari akuntansi biaya khususnya metode harga pokok pesanan. Penampilan yang berwarna-warni membuat kesan lebih "hidup", sehingga pengguna lebih tertarik untuk menggunakannya.

Revisi/perbaikan dilakukan dengan menambahkan materi-materi yang dianggap kurang terutama masalah bahasa. Menambahkan gambar, animasi, dan video yang sesuai sehingga diharapkan pengguna dapat mempelajari akuntansi biaya metode harga pokok pesanan dengan mudah dan nyaman kapan saja dan di mana saja.

Penilaian pada uji coba kelompok besar ini meliputi aspek pembelajaran, aspek materi, aspek media, saran terbuka, dan kesimpulan layak tidaknya multimedia digunakan. Ketigapuluh mahasiswa secara keseluruhan menilai aspek pembelajaran rata-rata 3,76 (baik), aspek materi 3,52 (baik), aspek media 3,83 (baik). 


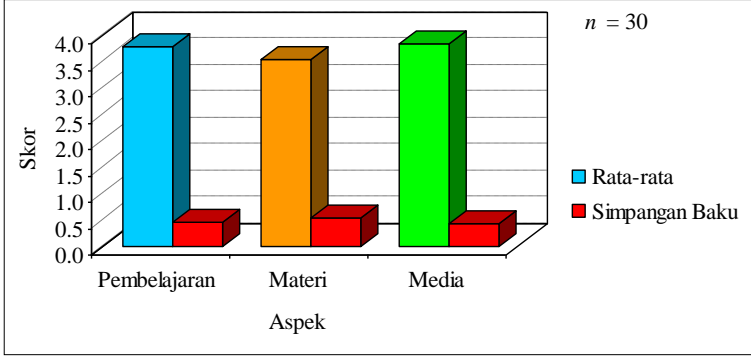

Gambar 3. Skor Rata-rata dan Simpangan Baku Hasil Uji coba Kelompok Besar pada Setiap Aspek

Data selanjutnya yang dikumpulkan untuk meyakinkan multimedia akuntansi biaya metode harga pokok pesanan baik atau tidak, peneliti mengumpulkan data hasil belajar aspek kognitif berupa nilai pre tes dan post tes tiga puluh mahasiswa yang memiliki laptop dan menggunakan multimedia. Jumlah mahasiswa kelas A 48 kelas B 48 mahasiswa yang memiliki laptop dan menggunakan multimedia untuk belajar kelas A17 kelas B 13 maka peneliti juga mengambil 17 mahasiswa kelas A dan 13 mahasiswa kelas B yang tidak mempunyai laptop dan tidak menggunakan multimedia untuk belajar dengan terlebih dahulu dilotere. Untuk lebih meyakinkan lagi bahwa multimedia akuntansi biaya baik digunakan maka peneliti mengumpulkan data nilai mahasiswa yang tidak mempunyai laptop dan tidak memakai multimedia untuk belajar. Hal ini peneliti bermaksud ingin mengetahui perbedaannya antara mahasiswa yang memiliki laptop dan menggunakan multimedia untuk belajar dengan mahasiswa yang tidak memiliki laptop dan tidak menggunakan multimedia.

Berdasarkan hasil analisis terhadap pretest dan posttest mahasiswa yang menggunakan multimedia dan mahasiswa yang tidak menggunakan multimedia, dapat diketahui bahwa dari ketigapuluh mahasiswa yang tidak menggunakan multimedia pembelajaran AB-MHPP memiliki nilai rata-rata pretest dan posttest sebesar 58,57 dan 67,88 , sehingga mengalami kenaikan sebesar 9,32 atau $15,91 \%$ dari pretest. Pengguna multimedia pembelajaran AB-
MHPP memiliki nilai rata-rata pretest dan posttest sebesar 58,77 dan 78,45, sehingga mengalami kenaikan sebesar 19,68 atau $33,61 \%$ dari pretest. Selengkapnya dapat dilihat pada Gambar 4.

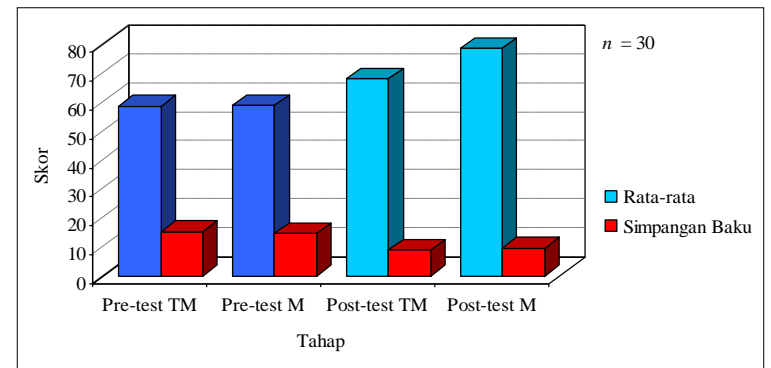

Gambar 4. Skor Rata-rata dan Simpangan Baku Hasil Uji coba Kelompok Besar pada Hasil Belajar Akuntansi Biaya Metode Harga Pokok Pesanan

Dari dua kelompok mahasiswa yang memiliki laptop dan menggunakan multimedia akuntansi biaya dan mahasiswa yang tidak memiliki laptop dan tidak menggunakan multimedia, ternyata kenaikan nilai pre tes ke post tes mahasiswa yang memiliki laptop dan menggunakan multimedia pembelajaran AB-MHPP sebesar 33,61\% dibandingkan dengan mahasiswa yang tidak memiliki laptop dan tidak menggunakan multimedia hanya sebesar $15,91 \%$. Berdasarkan deskripsi ini penggunaan multimedia pembelajaran AB-MHPP dapat dinyatakan lebih unggul dari pada yang tidak menggunakannya, namun perlu menguji signifikansi beda rata-rata agar lebih meyakinkan. Adapun pengujian beda rata-rata tersebut dilakukan pada bagian analisis data.

\section{Analisis Data}

Sesuai dengan data dan informasi hasil pra uji coba dan uji coba produk, selanjutnya dilakukan analisis mengenangi perkembangan mengenai kelayakan produk multimedia pembelajaran AB-MHPP yang dikembangkan. Aspek yang dianalisis dalam pengembangan produk ini terdiri atas aspek pembelajaran, materi, dan media serta keefektifannya. 
Aspek Pembelajaran

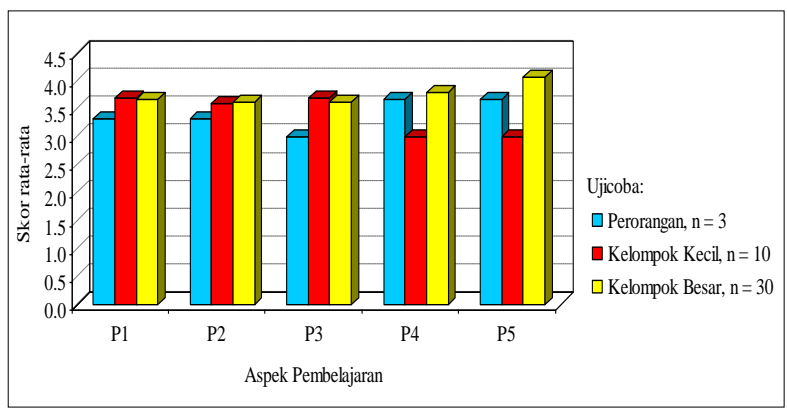

Gambar 5. Perbandingan Hasil Skor Ratarata pada Setiap Tahap Uji coba untuk Aspek

Pembelajaran

Aspek pembelajaran dalam produk multimedia pembelajaran AB-MHPP mencakup 5 indikator, yaitu kecukupan latihan untuk memahami materi; kecukupan latihan dan evaluasi untuk pencapaian kompetensi; respon atas jawaban benar/salah pada latihan; kekuatan media untuk membangkitkan motivasi belajar; dan daya du- kung media untuk menindaklanjuti materi selanjutnya (metode harga pokok proses). Perbandingan hasil skor rata-rata pada setiap tahap uji coba untuk aspek pembelajaran dapat dilihat pada Tabel 4. Berdasarkan Tabel 4, perbandingan hasil skor rata-rata pada setiap tahap uji coba untuk aspek pembelajaran dapat di-buat diagram batang seperti pada Gambar 5 .

\section{Aspek Materi}

Aspek materi dalam produk multimedia pembelajaran AB-MHPP mencakup 5 indikator, yaitu kemudahan materi untuk dipahami; kemudahan sajian materi untuk diikuti; kemudahan penggunaan bahasa untuk memahami materi; kemudahan contoh soal (BBB, BTKL, BOP) untuk dipahami; dan kemudahan latihan dan evaluasi untuk memahamkan materi. Perbandingan hasil skor rata-rata pada setiap tahap uji coba untuk aspek pembelajaran dapat dilihat pada Tabel 5 .

Tabel 4. Perbandingan Hasil Skor Rata-rata pada setiap Tahap Uji coba untuk Aspek Pembelajaran

\begin{tabular}{|c|c|c|c|c|}
\hline & \multirow[b]{2}{*}{ Indikator } & \multicolumn{3}{|c|}{ Skor Rata-rata pada Uji coba } \\
\hline & & Perorangan & $\begin{array}{l}\text { Kelompok } \\
\text { Kecil }\end{array}$ & $\begin{array}{l}\text { Kelompok } \\
\text { Besar }\end{array}$ \\
\hline P1 & Kecukupan latihan untuk memahami materi & 3.33 & 3.70 & 3.67 \\
\hline P2 & Kecukupan latihan dan evaluasi untuk pencapaian kompetensi & 3.33 & 3.60 & 3.63 \\
\hline P3 & Respon atas jawaban benar/salah pada latihan & 3.00 & 3.70 & 3.63 \\
\hline P4 & Kekuatan media untuk membangkitkan motivasi belajar & 3.67 & 3.00 & 3.80 \\
\hline P5 & $\begin{array}{l}\text { Daya dukung media untuk menindaklanjuti materi selanjutnya } \\
\text { (metode harga pokok proses) }\end{array}$ & 3.67 & 3.00 & 4.07 \\
\hline & Rata -rata & 3.40 & 3.40 & 3.76 \\
\hline
\end{tabular}

Tabel 5. Perbandingan Hasil Skor Rata-rata pada Setiap Tahap Uji coba untuk Aspek Materi

\begin{tabular}{llccc}
\hline \multicolumn{1}{c}{ Indikator } & \multicolumn{2}{c}{ Skor Rata-rata pada Uji coba } \\
& & \multicolumn{2}{c}{$\begin{array}{c}\text { Kelompok } \\
\text { Kelompok } \\
\text { Besar }\end{array}$} \\
\hline T1 Kemudahan materi untuk dipahami & 3.67 & 3.60 & 3.60 \\
T2 Kemudahan sajian materi untuk diikuti & 3.33 & 3.70 & 3.73 \\
T3 Kemudahan penggunaan bahasa untuk memahami materi & 3.00 & 3.40 & 3.17 \\
T4 Kemudahan contoh soal (BBB, BTKL, BOP) untuk dipahami & 3.67 & 3.50 & 3.63 \\
T5 Kemudahan latihan dan evaluasi untuk memahamkan materi & 3.00 & 3.40 & 3.47 \\
& Rata-rata & 3.33 & 3.52 & 3.52 \\
\hline
\end{tabular}


Berdasarkan Tabel 5, perbandingan hasil skor rata-rata pada setiap tahap uji coba untuk aspek materi dapat dibuat diagram batang seperti pada Gambar 6 .

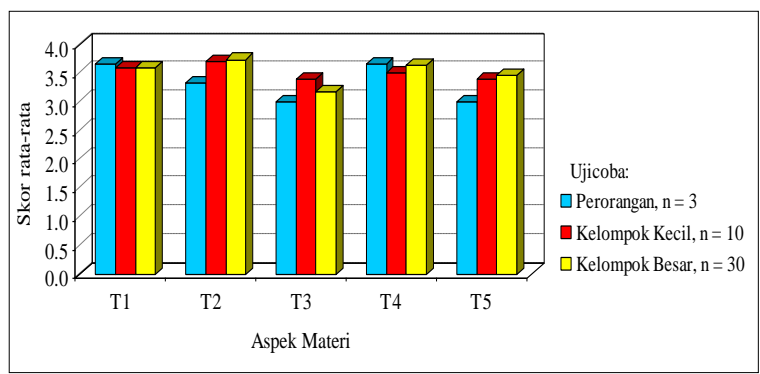

Gambar 6. Perbandingan Hasil Skor Ratarata pada Setiap Tahap Uji coba untuk Aspek Materi

Aspek Media

Aspek media dalam produk multimedia pembelajaran AB-MHPP mencakup 10 indikator, yaitu Kekonsistenan navigasi yang digunakan; animasi dan video memudahkan untuk memahami materi; daya dukung video dalam proses belajar; ketersediaan gambar; kualitas teks; komposisi dan kombinasi warna; kemudahan CD untuk digunakan; kualitas animasi sebagai daya dukung untuk memahami materi; tingkat kemenarikan penyajian materi; dan variasi media yang digunakan (teks, warna, audio, dan video). Perbandingan hasil skor rata-rata pada setiap tahap uji coba untuk aspek pembelajaran dapat dilihat pada Tabel 6 .

Berdasarkan Tabel 6, perbandingan hasil skor rata-rata pada setiap tahap uji coba untuk aspek materi dapat dibuat diagram batang. Berikut gambar diagram batang tersebut.

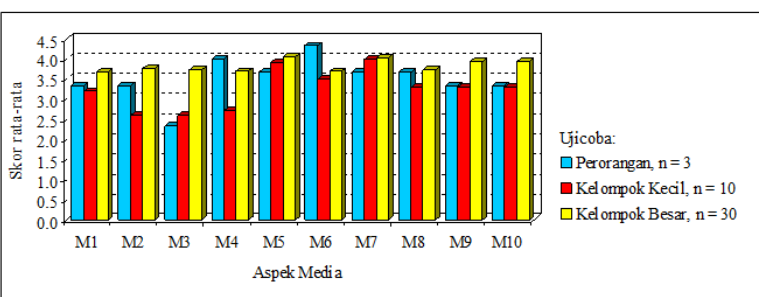

Gambar 7. Perbandingan Hasil Skor Ratarata pada Setiap Tahap Uji coba untuk Aspek Media

Keefektifan Multimedia Pembelajaran ABMHPP untuk Meningkatkan Hasil Belajar Aspek Kognitif

Keefektifan penggunaan multimedia pembelajaran AB-MHPP dapat diketahui dengan melakukan eksperimen, yaitu membandingkan rata-rata hasil belajar mahasiswa yang menggunakan multimedia dengan mahasiswa yang tidak menggunakan multimedia. Hal yang dibandingkan adalah hasil belajar akuntansi biaya metode harga pokok pesanan pada aspek kognitif. Eksperimen ini dilakukan dengan melibatkan dua kelompok, kelompok I adalah kelompok eksperimen berjumlah 30 mahasiswa yang pembelajarannya menggunakan multimedia AB-MHPP. Sedangkan untuk kelompok II adalah kelompok kontrol (kendali) berjumlah 30 mahasiswa yang pembelajarannya tidak menggunakan media tersebut.

Tabel 6. Perbandingan Hasil Skor Rata-rata pada Setiap Tahap Uji coba untuk Aspek Media

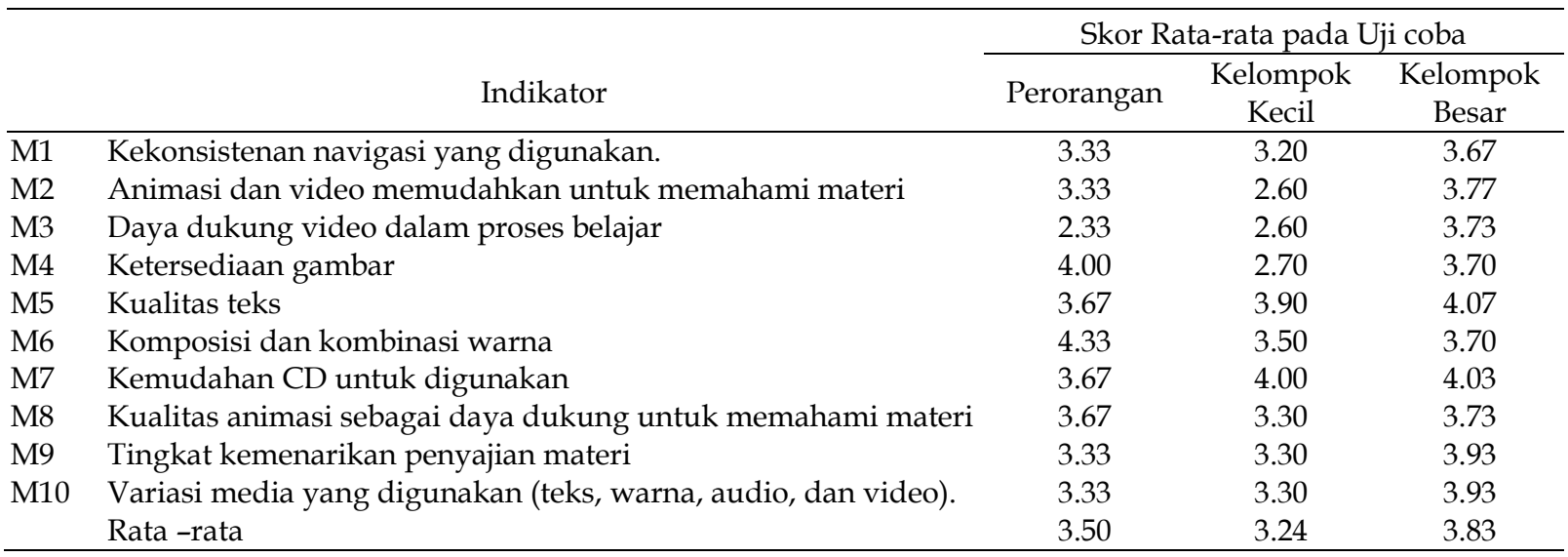


Desain eksperimen yang digunakan adalah pretest-posttest control group design dengan kelompok eksperimen (M) dan kelompok kontrol (TM). Hasil menunjukkan pada tahap pretest (sebelum treatment) untuk kelompok $\mathrm{M}$ memiliki skor rata-rata dan simpangan baku sebesar 58.77 dan 14.65, sedangkan kelompok TM sebesar 58.57 dan 15.27. Pada tahap posttest (setelah treatment), kelompok $\mathrm{M}$ memiliki skor rata-rata dan simpangan baku sebesar 78.45 dan 9.55, sedangkan untuk kelompok TM sebesar 67.88 dan 8.91. Selengkapnya dapat dilihat pada Tabel 7.

Setelah diketahui ukuran data, perlu dilakukan pengujian normalitas dan homogenitas sebagai prasyarat analisis pengujian beda rata-rata. Hasil pengujian normalitas sebaran data dapat dilihat pada Tabel 8.

Tabel 7. Ukuran Data

\begin{tabular}{lcccc}
\hline Ukuran & \multicolumn{2}{c}{ M } & \multicolumn{2}{c}{ TM } \\
& Pretest & Posttest & Pretest & Posttest \\
\hline Rata-rata & 58.77 & 78.45 & 58.57 & 67.88 \\
Simp Baku & 14.65 & 9.55 & 15.27 & 8.91 \\
Varian & 214.51 & 91.16 & 233.29 & 79.31 \\
Maksimal & 80.50 & 97.00 & 81.00 & 86.60 \\
Minimal & 28.50 & 54.00 & 5.50 & 44.00 \\
\hline
\end{tabular}

$\mathrm{M}=$ menggunakan multimedia AB-MHPP, $\mathrm{TM}=$ tidak menggunakan

Tabel 8. Hasil Uji Normalitas

\begin{tabular}{llccc}
\hline Tes & Kelompok & $K S-Z$ & $p$ & Keterangan \\
\hline Pre & M & 0.140 & 0.141 & Normal \\
& TM & 0.148 & 0.094 & Normal \\
Post & M & 0.119 & 0.200 & Normal \\
& TM & 0.105 & 0.200 & Normal \\
\hline
\end{tabular}

$\mathrm{M}=$ menggunakan multimedia $\mathrm{AB}-\mathrm{MHPP}$,

$\mathrm{TM}=$ tidak menggunakan

Berdasarkan Tabel 8, distribusi atau sebaran data pada masing-masing kelompok dapat dianggap normal. Kriteria dapat dianggap berdistribusi normal bila statistik uji yang digunakan yaitu Kolmogorov Smirnov $Z$ (KS-Z) memiliki proporsi $(p)$ yang lebih besar dari 0.05 (level signifikansi). Hasil menunjukkan bahwa $p$ untuk KS-Z pretest $\mathrm{M}$ dan TM, serta posttest $\mathrm{M}$ dan TM secara berturut-turut adalah 0.141, 0.094, 0,200 , dan 0,200. Oleh karena keseluruhannya lebih besar dari 0.05 sehingga distribusi data pada setiap kelompok dan tahapan tes dapat dinyatakan normal. Sesuai dengan hasil ini maka syarat distribusi normal terpenuhi.

Setelah pengujian distribusi dilakukan, selanjutnya dilakukan pengujian terhadap variansi untuk mengetahui apakah varian dua kelompok yang dibandingkan dapat dinyatakan homogen atau heterogen. Statistik uji yang digunakan dalam pengujian ini adalah uji $\mathrm{F}$, dengan kriteria dinyatakan homogen apabila $F<F_{a}\left(\mathrm{v}_{1} ; \mathrm{v}_{2}\right)$ atau $p>0.05$. Hasil pengujian homogenitas dapat dilihat pada Tabel 9.

Tabel 9. Hasil Uji Homogenitas

\begin{tabular}{|c|c|c|c|c|c|c|c|}
\hline Tes & Kel & Varian & $\mathrm{db}$ & $F$ & $F_{0.05}$ & $p$ & Ket \\
\hline \multirow[t]{2}{*}{ Pre } & M & 214.51 & $1 ; 58$ & 0.077 & 4.000 & 0.782 & Hom \\
\hline & $\mathrm{TM}$ & 233.29 & & & & & \\
\hline \multirow[t]{2}{*}{ Post } & M & 91.16 & $1 ; 58$ & 0.133 & 4.000 & 0.717 & Hom \\
\hline & $\mathrm{TM}$ & 79.31 & & & & & \\
\hline
\end{tabular}

Berdasarkan hasil analisis yang ditunjukkan dalam Tabel 9, pada tahap pretest memiliki $F(0.077)<F_{0.05}(1 ; 58)=4.000$ dan $p(0.782>0.05)$ sehingga dapat dinyatakan homogen. Sedangkan pada tahap posttest memiliki $F(0.133)<F_{0.05}(1 ; 58)=4.000$ dan $p(0.717>0.05)$ sehingga dapat dinyatakan homogen. Syarat varian data yang dibandingkan bersifat homogen terpenuhi sehingga uji beda rata-rata dapat dilakukan.

Setelah melalui pengujian prasyarat analisis untuk uji beda rata-rata yaitu normalitas dan homogenitas, maka selanjutnya dilakukan uji beda rata-rata untuk mengetahui perbedaan hasil belajar kelompok $\mathrm{M}$ atau yang menggunakan multimedia pembelajaran AB-MHPP dengan yang tidak (TM). Penggunaan mulimedia pembelajaran AB-MHPP dinyatakan lebih efektif atau unggul apabila lebih meningkatkan hasil belajar dari pada yang tidak menggunakan. Hasil uji beda rata-rata dapat dilihat pada Tabel 10. 
Tabel 10. Hasil Uji Beda Rata-rata

\begin{tabular}{llcccccc}
\hline Tes & Kel & Rerata & $\mathrm{db}$ & $t$ & $t_{0.05}$ & $p$ & Ket \\
\hline Pre & M & 58.77 & 58 & 0.052 & 1.671 & 0.959 & Sama \\
& TM & 58.57 & & & & & \\
Post & M & 78.45 & 58 & 4.433 & 1.671 & 0.000 & $\begin{array}{l}\text { Beda } \\
\text { Signf }\end{array}$ \\
& & & & & & & \\
& TM & 67.88 & & & & & \\
\hline
\end{tabular}

Berdasarkan informasi tabel tersebut, tahap pretest dapat dinyatakan tidak memiliki perbedaan signifikan atau kedua kelompok memiliki kemampuan yang sama secara rata-rata, karena $t(0.052)<t_{0.05}$ $(58)=1.671$ dan $p(0.959>0.05)$. Pada tahap posttest dapat dinyatakan memiliki perbedaan signifikan atau kedua kelompok memiliki kemampuan yang berbeda secara rata-rata, karena $t(4.433)>t_{0.05}(58)=1.671$ dan $p(0.000<0.05)$. Hasil belajar awal (kemampuan awal/pretest) untuk kedua kelompok dianggap sama sedangkan pada tahap posttest hasil belajar akhir dinyatakan berbeda secara signifikan berdasarkan rataratanya.

Melihat skor rata-rata posttest kelompok $\mathrm{M}$ atau yang menggunakan multimedia pembelajaran AB-MHPP $(\mathrm{M}=78.45)$ lebih tinggi dari pada yang tidak menggunakannya $(\mathrm{TM}=67.88)$, berarti penggunaan multimedia pembelajaran ABMHPP dalam pembelajaran akuntansi biaya metode harga pokok pesanan lebih efektif atau lebih unggul dari pada yang tidak menggunakannya.

Berdasarkan uji coba produk dan analisis data, dapat diketahui bahwa produk hasil pengembangan layak untuk digunakan. Selain itum penggunaaan multimedia pembelajaran Akuntansi Biaya dapat meningkatkan keefektifan pembelajaran yang tentunya diikuti dengan meningkatnya hasil belajar mahasiswa.

\section{Simpulan dan Saran}

Simpulan

Produk hasil penelitian dan pengembangan ini berupa multimedia pembelajaran AB-MHPP. Simpulan atas hasil penelitian dan pengembangan mengenai proses pengembangan, kelayakan, dan keefektifan multimedia pembelajaran ABMHPP adalah sebagai berikut: (1) multimedia pembelajaran AB-MHPP dinyatakan layak ditinjau dari aspek pembelajaran, materi, media; (2) multimedia pembelajaran AB-MHPP efektif untuk meningkatkan hasil belajar Akuntansi Biaya Metode Harga Pokok Pesanan.

Saran

Beberapa saran yang dapat diberikan dan diperhatikan antara lain adalah sebagai berikut. Pertama, dosen hendaknya memiliki inisiatif mengembangkan media pembelajaran guna meningkatkan kualitas pembelajaran dan tujuan pembelajaran yang lebih cepat tercapai. Kedua, mahasiswa hendaknya memberikan apresiasi positif apabila dosennya memiliki inisiatif melakukan pengembangan media pembelajaran. Bentuk apresiasi positif tersebut dapat ditunjukkan dengan memberikan dukungan informasi kebutuhan dalam pembelajaran. Ketiga, meskipun dosen telah memiliki multimedia pembelajaran ABMHPP dan mahasiswa dapat belajar secara mandiri, namun dosen tetap harus memantau belajar mahasiswa dan menyampaikan materi-materi tambahan yang relevan. Keempat, multimedia pembelajaran ABMHPP perlu dikembangkan lebih lanjut menggunakan aplikasi macromedia flash atau sejenisnya agar mampu berfungsi interaktif.

\section{Daftar Pustaka}

Bell Gredler, E. M. (1991). Belajar dan membelajarkan. Jakarta: CV. Rajawali.

Borg, W. R. \& Gall, Meredith D. (1983). Educational research an introduction ( $4^{\text {th }}$ ed). New York: Longman Inc.

Budiningsih, C. A. (2005). Belajar dan pembelajaran. Jakarta : Rineka Cipta.

Dick, W., Carey, L., \& Carey, J. (2009). The systematic design of instruction ( $6^{\text {th }}$ ed). Boston: Parson. 
Mukminan. (2006). Desain Pembelajaran. Yogyakarta: Program Sarjana Universitas Negeri Yogyakarta.

Newby, T.J, Stepich, D.A, Lehman, J.D, and Russel, J.D. (2000). Instructional technology for teaching and learning. New Jersey: Merrill.

Slavin, R.E. (2000). Educational psychology: theory and practice. (6 $\left.6^{\text {th }} \mathrm{ed}\right)$. Boston: Allyn and Bacon.
Sukardjo, dkk.(2006). Evaluasi pembelajaran. Hand out perkuliahan mata kuliah Evaluasi Pembelajaran pada Program Studi Teknologi Pembelajaran di PPs UNY.

Uno, H. B. (2008). Perencanaan pembelajaran. Jakarta: Bumi Aksara. 